\title{
Analisis Jumlah Pengunjung dan Jumlah Wisata Terhadap PAD Kabupaten Lamongan
}

\author{
Haykal Abidin ${ }^{1}$, Awawin Mustana Rohmah² \\ ${ }^{1}$ Universitas Islam Darul Ulum, haykal1991abidin@gmail.com \\ ${ }^{2}$ Universitas Islam Darul Ulum, awawin.emer@gmail.ac.id
}

\begin{abstract}
Lamongan Regency is one of the regencies in East Java which is quite potential to support economic needs. One of the potentials in Lamongan is the entertainment and recreation sector, in this case tourism. Tourism is one of the sectors that has experienced an increase in investment so that it is able to increase economic activity and have an impact on Regional Original Income (PAD). To determine the effect of the amount of tourism on PAD in Lamongan Regency, multiple linear regression analysis and determination coefficient analysis were carried out. The results of this study indicate that the number of tourists greatly influences the PAD in Lamongan Regency and has increased.
\end{abstract}

Keywords: Amount of Tourism on PAD Lamongan, multiple linear regression analysis, determination coefficient analysis

\begin{abstract}
Abstrak. Kabupaten Lamongan merupakan salah satu kabupaten di Jawa Timur yang cukup potensial untuk menunjang kebutuhan ekonomi. Salah satu potensi di Lamongan adalah sektor hiburan dan rekreasi dalam hal ini Pariwisata. Pariwisata menjadi salah satu sektor yang mengalami kenaikan investasi sehingga mampu meningkatkan kegiatan ekonomi dan berdampak pada Pendapatan Asli Daerah (PAD). Untuk mengetahui pengaruh Jumlah Wisata pada PAD Kabupaten Lamongan dilakukan analisa Regresi Linier Berganda dan Analisa Koefisen Determinasi. Hasil dari penelitian ini yaitu jumlah wisatawan sangat memepengaruhi dalam PAD di Kabupaten Lamongan dan mengalami peningkatan.
\end{abstract}

Kata Kunci: Jumlah Wisata, PAD Kab Lamongan, Analisa Regresi Linier Berganda, Analisa Koefisien Determinasi.

\section{Pendahuluan}

Kabupaten Lamongan merupakan salah satu kabupaten di Propinsi Jawa Timur dengan kondisi geografis yang cukup potensial. Sektor pertanian dan perikanan dapat dipandang sebagai salah satu kunci sukses pemerintah kabupaten Lamongan dalam mewujudkan kesejahteraan masyarakat [1]. Perikanan merupakan salah satu kegiatan usaha dari subsektor pertanian yang memiliki peran sangat penting di kabupaten Lamongan [2].

Selain sektor pertanian dan perikanan, kabupaten Lamongan juga memungkinkan adanyah kegiatan ekonomi lainnya yang cukup beragam. Dari keberagaman wilayah tersebut Kabupaten Lamongan memiliki potensi ekonomi di empat sektor yaitu sektor pertanian dengan subsektor tanaman pangan dan perikanan, sektor perdagangan, hotel, dan restauran, sektor jasa dengan subsektor 
swasta hiburan dan rekreasi, sektor pengolahan dengan industri utama makan, rokok, tekstil, barang kulit. barang kayu, kertas dan barang cetakan.

Keempat sektor inilah yang menjadi penopang kegiatan ekonomi Kabupaten Lamongan. Salah satu sektor yang menarik dari empat sektor yang menopang kegiatan ekonomi Kabupaten Lamongan adalah sektor rekreasi dan hiburan. Rekreasi dan hiburan dapat dimasukkan dalam kegiatan pariwisata [3]. Dalam kurun waktu 6 tahun pariwisata masuk menjadi salah satu sektor yang mengalami kenaikan investasi dan mampu meningkatkan kegiatan ekonomi yang berdampak pada Pendapatan Asli Daerah (PAD). Salah satu pariwisata unggulan yang berada di Kabupaten Lamongan yang menjadi ikon adalah Wisata Bahari Lamongan (WBL).

Kunjungan wisatawan ke obyek wisata unggulan Lamongan mengalami pola kunjungan yang cukup signifikan dalam beberapa tahun terakhir selain sebagai tujuan bisnis juga sebagai sumber PAD kabupaten Lamongan,serta dalam perkembangannya kunjungan wisatawan ke 8 wisata perlu dilakukan analisis dan penelitian untuk mengetahui pola (pattern) data kunjungan dan tujuan utama obyek wisata yang diakibatkan oleh sebuah perubahan. Berdasarkan latar belakang yang telah diuraikan, peneliti akan meneliti ada tidaknya pengaruh jumlah pengunjung terhadap PAD Lamongan dalam sektor pariwisata.

\section{Metode Penelitian}

Metode yang digunakan dalam penelitian ini yaitu menggunakan data sekunder, peneliti mengambil data dari catatan bagian pengelolaan data pada BPS Lamongan [4]. Data yang diambil adalah data runtun waktu perbulan selama tujuh tahun. Variabel yang digunakan adalah jumlah kunjungan wisata di Lamongan. Selanjutnya dilakukan Analisa dengan Uji Normalitas Data, Uji Asumsi Klasik, Analisa Regresi Linier Berganda, dan Analisa Koefisien Determinasi [5].

\section{Hasil dan Pembahasan}

Hasil dari pengolahan dan Pengumpulan data dilakukan perhitungan dengan SPSS, sehingga hasil pengolahan data dapat dilihat sebagai berikut.

\subsection{Uji Asumsi Klasik}

\subsubsection{Uji Normalitas Data}

Berdasarkan uji normalitas ditunjukkan oleh Tabel 1 bahwa data yang diperoleh adalah berdistribusi normal dengan nilai rasio skeweness $=1,101$ / $0,845=1,195266$; sedang rasio kurtosis $=1,180 / 1,741=0,677$. Dengan rasio skewness dan rasio kurtosis berada di antara -2 hingga +2 (Sugiyono, 2012).

Tabel 1. Hasil Uji Normalitas

\begin{tabular}{|c|c|c|c|c|c|c|c|c|c|}
\hline & \multirow{2}{*}{$\begin{array}{c}\mathrm{N} \\
\text { Stat }\end{array}$} & \multirow{2}{*}{$\begin{array}{c}\text { Minimum } \\
\text { Stat }\end{array}$} & \multirow{2}{*}{$\begin{array}{c}\text { maximum } \\
\text { Stat }\end{array}$} & \multirow{2}{*}{$\begin{array}{l}\text { Mean } \\
\text { Stat }\end{array}$} & \multirow{2}{*}{$\begin{array}{c}\text { Std. Deviation } \\
\text { Stat }\end{array}$} & \multicolumn{2}{|c|}{ Skewness } & \multicolumn{2}{|c|}{ Kurtosis } \\
\hline & & & & & & Stat & $\begin{array}{l}\text { Std. } \\
\text { Error }\end{array}$ & Stat & $\begin{array}{l}\text { Std. } \\
\text { Error }\end{array}$ \\
\hline $\begin{array}{l}\text { Unstanardized } \\
\text { Residual }\end{array}$ & 6 & $-2.37 \mathrm{E} 10$ & $3.7272 \mathrm{E} 10$ & $\ldots$ & $2.1578549 \mathrm{E} 10$ & 1.101 & .845 & 1.180 & 1.741 \\
\hline $\begin{array}{l}\text { Valid N } \\
\text { (listwise) }\end{array}$ & 6 & & & & & & & & \\
\hline
\end{tabular}




\subsubsection{Uji Multikolinearitas}

Dalam Uji multikolinearitas digunakan Uji VIF. Uji ini hanya melihat nilai VIF untuk masing-masing variabel lebih besar dari 10 atau tidak yang dijelaskan pada Tabel 2 berikut.

Tabel 2. Uji Multikolinearitas

\begin{tabular}{|c|c|c|c|c|c|c|c|c|}
\hline & \multirow[t]{2}{*}{ Model } & \multicolumn{2}{|c|}{ Unstandardized Coefficients } & $\begin{array}{l}\text { Standardized } \\
\text { Coefficients }\end{array}$ & \multirow[t]{2}{*}{$\mathrm{t}$} & \multirow[t]{2}{*}{ Sig. } & \multicolumn{2}{|c|}{ Collinearity Statistics } \\
\hline & & B & Std. Error & Beta & & & Tolerance & VIF \\
\hline \multirow[t]{3}{*}{1} & (Constant) & 2.249E10 & $6.406 \mathrm{E} 10$ & & .351 & .749 & & \\
\hline & jumlah_objek & $1.402 \mathrm{E} 10$ & $1.150 \mathrm{E} 10$ & .242 & 1.219 & .310 & .434 & 2.302 \\
\hline & jumlah_pengunjung & 1982.305 & 506.545 & .778 & 3.913 & .030 & .434 & 2.302 \\
\hline
\end{tabular}

Berdasarkan hasil tersebut, diperoleh bahwa nilai dari VIF dibawah 10 maka dapat disimpulkan bahwa model regresi ini tidak memiliki masalah multikolinieritas.

\subsubsection{Uji Heteroskedastisitas}

Uji Heteroskedastisitas dilakukan untuk menguji apakah ada model regresi terjadi ketidaksamaan varians residual dari satu pengamatan ke pengamatan yang lain. Dalam Uji ini digunakan Uji Glesjer yang ditunjukkan pada Tabel 3 berikut.

Gambar 3. Uji Heteroskedastisitas

\begin{tabular}{|c|c|c|c|c|c|c|c|c|}
\hline & \multirow[t]{2}{*}{ Model } & \multicolumn{2}{|c|}{ Unstandardized Coefficients } & $\begin{array}{c}\text { Standardized } \\
\text { Coefficients }\end{array}$ & \multirow[t]{2}{*}{$\mathrm{t}$} & \multirow[t]{2}{*}{ Sig. } & \multicolumn{2}{|c|}{ Collinearity Statistics } \\
\hline & & B & Std. Error & Beta & & & Tolerance & VIF \\
\hline \multirow[t]{3}{*}{1} & (Constant) & $-3.47 \mathrm{E} 10$ & $1.970 \mathrm{E} 10$ & & -1761 & .176 & & \\
\hline & jumlah_objek & $8.701 \mathrm{E} 9$ & $3.538 \mathrm{E} 9$ & 1.159 & 2.459 & .091 & .434 & 2.302 \\
\hline & jumlah_pengunjung & -170.420 & 155.811 & -.516 & -1.094 & .354 & .434 & 2.302 \\
\hline
\end{tabular}

a. Dependent Variable: Abresid

\subsection{Analisa Regresi Linier Berganda}

Analisis regresi berganda digunakan untuk mengetahui Pengaruh Jumlah Wisatawan, jumlah obyek wisata, terhadap Pendapatan Asli Daerah Sektor Pariwisata di Kabupaten Lamongan. Berdasarkan perhitungan yang dilakukan dengan program SPSS. Maka hasil pengolahan data diperoleh ditunjukkan pada Tabel 4 berikut.

Tabel 4. Hasil Analisa Regresi Linier Berganda

\begin{tabular}{|c|c|c|c|c|c|}
\hline \multirow[t]{2}{*}{ Model } & \multicolumn{2}{|c|}{ Unstandardized Coefficients } & \multirow{2}{*}{$\begin{array}{c}\begin{array}{c}\text { Standardized } \\
\text { Coefficients }\end{array} \\
\text { Beta } \\
\end{array}$} & \multirow[t]{2}{*}{$\mathrm{t}$} & \multirow[t]{2}{*}{ Sig. } \\
\hline & $\mathrm{B}$ & Std. Error & & & \\
\hline 1 (Constant) & $2.249 \mathrm{E} 10$ & $6.406 \mathrm{E} 10$ & & .351 & .749 \\
\hline jumlah_objek & $1.402 \mathrm{E} 10$ & $1.150 \mathrm{E} 10$ & .242 & 1.219 & .310 \\
\hline jumlah_pengunjung & 1982.305 & 506.545 & .778 & 3.913 & .030 \\
\hline
\end{tabular}


Berdasarkan Tabel 5, diperoleh persamaan model regresi berganda yaitu $y=1,402 X_{1}+1982,305 X_{2}+2,249$

Pengaruh Jumlah Wisata Terhadap Pendapatan Asli Daerah Sektor Pariwisata di Kabupaten Lamongan. Diperoleh koefisien regresi untuk variabel Jumlah Wisata sebesar 1,402, hal ini berarti apabila terjadi kenaikan pada Jumlah Wisata sebesar $1 \%$, maka akan terjadi kenaikan pada pendapatan pariwisata sebesar $1,402 \%$. Sehingga dapat disimpulkan bahwa semakin banyak jumlah wisata yang berkunjung ke kabupaten Lamongan maka pendapatan daerah sektor pariwisata yang diterima akan semakin meningkat, sebaliknya jika jumlah wisata yang berkunjung mengalami penurunan maka pendapatan daerah sektor pariwisata yang diterima akan semakin menurun. Hal ini Sesuai dengan teori yang menyatakan bahwa kedatangan wisatawan merupakan sumber penerimaan bagi daerah atau negara, baik dalam bentuk devisa atau penerimaan pajak dan retribusi. Semakin banyak wisatawan yang berkunjung ke obyek wisata maka tiket masuk obyek wisata yang terjual akan semakin banyak, kemudian berpengaruh pada peningkatan PAD kabupaten Lamongan. Hasil penelitian menunjukan bahwa Jumlah Wisata berhubungan Positif dan signifikan terhadap Pendapatan Asli Daerah Sektor Pariwisata sesuai dengan hipotesis yang diajukan, maka hipotesis dalam penelitian ini diterima

Pengaruh Jumlah Wisatawan Terhadap Pendapatan Asli Daerah Sektor Pariwisata di Kabupaten Lamongan. Diperoleh koefisien regresi untuk variabel Jumlah Wisatawan sebesar 1982,305, hal ini berarti apabila terjadi kenaikan pada Jumlah Wisata sebesar 1\%, maka akan terjadi kenaikan pada pendapatan pariwisata sebesar 1982,305\%. Sehingga dapat disimpulkan bahwa semakin banyak jumlah wisatawan yang berkunjung ke kabupaten Lamongan maka pendapatan daerah sektor pariwisata yang diterima akan semakin meningkat, sebaliknya jika jumlah wisatawan yang berkunjung mengalami penurunan maka pendapatan daerah sektor pariwisata yang diterima akan semakin menurun. Hal ini Sesuai dengan teori yang menyatakan bahwa kedatangan wisatawan merupakan sumber penerimaan bagi daerah atau negara, baik dalam bentuk devisa atau penerimaan pajak dan retribusi. Semakin banyak wisatawan yang berkunjung ke obyek wisata maka tiket masuk obyek wisata yang terjual akan semakin banyak, kemudian berpengaruh pada peningkatan PAD kabupaten Lamongan. Hasil penelitian menunjukan bahwa Jumlah Wisatawan berhubungan Positif dan signifikan terhadap Pendapatan Asli Daerah Sektor Pariwisata sesuai dengan hipotesis yang diajukan, maka hipotesis dalam penelitian ini diterima.

\subsection{Pengujian Hipotesis}

\subsubsection{Uji F}

Dalam Uji ini membandingkan antara hasil Tabel dengan perhitungan dengan menggunakan angka signifikansi berikut. 
1) Apabila angka signifikansi $>0,05$, maka Ho diterima dan Ha ditolak.

2) Apabila angka signifikansi $<0,05$, maka Ho ditolak atau Ha diterima.

Tabel 5. ANOVA

\begin{tabular}{|c|c|c|c|c|c|c|}
\hline & Model & $\begin{array}{l}\text { Sum of } \\
\text { Squares }\end{array}$ & df & Mean Square & $\mathrm{F}$ & Sig \\
\hline \multirow[t]{3}{*}{1} & Regression & $4.283 \mathrm{E} 22$ & & 2.141E22 & 27.593 & $.012^{\mathrm{a}}$ \\
\hline & Residual & $2.328 \mathrm{E} 21$ & & 7.761E20 & & \\
\hline & Total & $4.516 \mathrm{E} 22$ & & & & \\
\hline
\end{tabular}

a. Predictors: (Constant), jumlah_pengunjung, jumlah_objek

b. Dependent Variable: PAD

Berdasarkan Tabel 5. menunjukan nilai uji F sebesar 27,593 dengan nilai signifikasi 0.012 , dimana disyaratkan nilai signifikasi $\mathrm{F}$ lebih kecil dari lima persen, agar hipotesis dapat diterima. Dari hasil regresi, signifikasi $\mathrm{F}$ sebesar 0.012 lebih kecil dari tingkat $\alpha($ alpha $)=0.05$ (5\%). Dengan demikian dapat diambil kesimpulan bahwa semua variabel independen dalam penelitian ini secara bersama-sama (simultan) berpengaruh terhadap Pendapatan Asli Daerah Sektor Pariwisata di Kabupaten Lamongan. Hal tersebut berarti jika Jumlah Wisatawandan jumlah wisata secara bersama-sama mengalami kenaikan maka akan berdampak pada kenaikan Pendapatan Asli Daerah Sektor Pariwisata di Kabupaten Lamongan, sebaliknya Jumlah Wisatawandan jumlah wisata secara bersama-sama mengalami penurunan maka akan berdampak pada turunnya Pendapatan Asli Daerah Sektor Pariwisata di Kabupaten Lamongan.

\subsection{Analisis Koefisien Determinasi}

Berdasarkan hasil analisis menggunakan SPSS diperoleh hasil berikut.

Tabel 6. Hasil Koefisien Determinasi

\begin{tabular}{llllll}
\hline Model & R & R Square & Adjusted R Square & Std. Error of the Estimate & Durbin-Watson \\
\hline 1 & $.974^{\mathrm{a}}$ & .948 & .914 & $2.78578 \mathrm{E} 10$ & 3.375 \\
\hline a. Predictors: (Constant), jumlah_pengunjung, jumlah_objek & \\
b. Dependent Variable: PAD
\end{tabular}

Besarnya koefisien determinasi ( $\left.\mathrm{R}_{2}\right)$ sebesar 0.914 atau 91,4 persen, sehingga dapat dikatakan bahwa 91,4 persen variabel terikat yaitu variabel Pendapatan Asli Daerah di Kabupaten Lamongan pada model dapat dijelaskan oleh variabel bebas yaitu variabel Jumlah Wisatawan dan jumlah wisata sedangkan sisanya 8.6 persen dipengaruhi oleh variabel lain di luar model. 


\section{Simpulan}

Berdasarkan Hasil dan Pembahasan dapat disimpulkan bahwa Pengaruh Jumlah Wisata Terhadap Pendapatan Asli Daerah Sektor Pariwisata di Kabupaten Lamongan diperoleh koefisien regresi untuk variabel Jumlah Wisata sebesar 1,402, hal ini berarti apabila terjadi kenaikan pada Jumlah Wisata sebesar 1\%, maka akan terjadi kenaikan pada pendapatan pariwisata sebesar 1,402\%. Hal lain yang dapat mempengaruhi adalah Jumlah Wisatawan Terhadap Pendapatan Asli Daerah Sektor Pariwisata di Kabupaten Lamongan. Diperoleh koefisien regresi untuk variabel Jumlah Wisatawan sebesar 1982,305, hal ini berarti apabila terjadi kenaikan pada Jumlah Wisata sebesar 1\%, maka akan terjadi kenaikan pada pendapatan pariwisata sebesar 1982,305\%. Ini berarti bahwa semakin banyak jumlah wisata yang berkunjung ke Kabupaten Lamongan maka pendapatan daerah sektor pariwisata yang diterima akan semakin meningkat, sebaliknya jika jumlah wisata yang berkunjung mengalami penurunan maka pendapatan daerah sektor pariwisata yang diterima akan semakin menurun.

\section{Daftar Pustaka}

[1] A. Rohmatullah, D. Rahmalia, and M. S. Pradana, "Klasterisasi Data Pertanian di Kabupaten Lamongan Menggunakan Algoritma K-Means Dan Fuzzy C Means," J. Ilm. Teknosains, vol. 5, no. 2, pp. 86-93, 2019.

[2] M. S. Pradana, D. Rahmalia, and E. D. A. Prahastini, "Peramalan Nilai Tukar Petani Kabupaten Lamongan dengan Arima," J. Mat., vol. 10, no. 2, pp. 91-104, 2020.

[3] I. Pitana and I. Diarta, "Pengantar ilmu pariwisata," 2009.

[4] BPS, Lamongan dalam Angka. Lamongan: BPS Kab Lamongan.

[5] I. Ghozali, "Aplikasi multivariate dengan program IBM SPSS 19," Semarang Badan Penerbit Univ. Diponegoro, 2011. 